\title{
Potential host colonization by insect herbivores in a warmer climate: a transplant experiment
}

\author{
NIGEL R. ANDREW and LESLEY HUGHES \\ Key Centre for Biodiversity and Bioresources, Department of Biological Sciences, Macquarie University, Sydney, NSW, Australia
}

\begin{abstract}
We conducted a transplant experiment to investigate the potential colonization of a plant species by insect herbivores under a warmer climate. Acacia falcata seeds collected from four latitudes, encompassing the current coastal range of the species $(1150 \mathrm{~km})$, were grown in the same soil type and climatic conditions in a glasshouse. Plants were then transplanted to two sites, $280 \mathrm{~km}$ north of $A$. falcata's current coastal range; the transplant sites were 1.2 and $5.5^{\circ} \mathrm{C}$ warmer than the northernmost and southernmost boundaries of the species' current range, respectively. We compared the structure and composition of the herbivorous Hemiptera and Coleoptera communities on the transplants (i) to that of A. falcata within its current distribution, (ii) to a closely related Acacia species (Acacia leptostachya) that naturally occurred at the transplant sites, and (iii) among the A. falcata transplants originating from seeds collected at different latitudes. Herbivory on A. falcata was also compared between the transplants and the current distribution, and among transplant originating from different latitudes. Thirty species of externally feeding herbivorous Coleoptera and Hemiptera were collected from the transplanted A. falcata over a period of $\mathbf{1 2}$ months following transplantation. Guild structure of this herbivore community (based on the proportion of species within each of seven groups based on taxonomy and feeding style) did not significantly differ between the transplants and that found on $A$. falcata within its natural range, but did differ between the transplants and A. leptostachya. Rates of herbivory did not significantly differ between the transplants and plants at sites within the natural range. There were no significant differences in herbivore species richness or overall rates of herbivory on the transplants originating from different latitudes. In conclusion, host plant identity was apparently more important than climate in influencing the structure of the colonizing herbivore community. If this result holds for other plant-herbivore systems, we might expect that under a warmer climate, broad patterns in insect community structure and rates of herbivory may remain similar to that at present, even though species composition may change substantially.
\end{abstract}

Keywords: Acacia, Australia, climate change, Coleoptera, community structure, Hemiptera, phytophagous insect, transplant experiment

Received 22 October 2004; revised version received 25 January 2005 and accepted 28 February 2005

Introduction

Global temperatures have increased approximately $0.6^{\circ} \mathrm{C}$ over the past century and climate models predict increases of $1.4-5.8^{\circ} \mathrm{C}$ by 2100 (IPCC, 2001). The abundance and distribution of species has already been affected by anthropogenic climate change over the past

Correspondence: N. R. Andrew, Discipline of Zoology, University of New England, NSW 2351, Australia, tel. + 6126773 2937, fax + 6126773 3814, e-mail: nigel.andrew@une.edu.au

(C) 2007 The Authors

Journal compilation (C) 2007 Blackwell Publishing Ltd few decades with poleward shifts in geographical ranges documented for a wide variety of taxa (e.g. Parmesan et al., 1999; Crozier, 2002; Walther et al., 2002; Root et al., 2003). Individualistic responses of species to current and future changes, especially differential migration rates, will result in the progressive decoupling of present day ecological interactions, together with the formation of new relationships, potentially leading to profound changes in the structure and composition of present day communities (Hughes, 2000; Harrington et al., 2001). 
In this study, we investigated how the relationship of herbivorous insects and their host plants may change under a warmer climate. We focused on herbivorous insect communities for several reasons. First, insect herbivores comprise a significant portion of global biodiversity, representing about a million of the 1.75 million described species (e.g. Jones \& Lawton, 1991; Price, 2002). Second, herbivores have significant impacts on productivity, decomposition, nutrient-cycling and other important ecosystem-level processes (e.g. Kremen et al., 1993). Third, many insect herbivores are highly mobile, and may, therefore, be expected to migrate rapidly in response to shifting climate zones. If the migration rates of their host plants lag behind, a reasonable expectation given what is known about plant dispersal rates under past climate changes (Huntley \& Webb, 1989; Webb, 1992), we might expect herbivores to colonize new plant species and conversely, for host species to be subject to new suites of herbivores within their current range in the short to medium term.

Transplant experiments offer a powerful method of testing hypotheses about how species and communities will be affected by future climatic changes although there are relatively few published studies using this technique (but see Wieder \& Yavitt, 1994; Hobbie \& Chapin, 1998; Shaw \& Harte, 2001; Bruelheide, 2003). CSIRO climate models project a $1-5^{\circ} \mathrm{C}$ warming along the east coast of Australia over the next 70 years (CSIRO, 2001). We investigated whether broad changes in herbivore community structure and/or composition will occur as the climate warms, by transplanting a host plant species to locations subject to mean annual temperatures $1.2^{\circ} \mathrm{C}$ higher than at the species' current warmest boundary and $5.5^{\circ} \mathrm{C}$ higher than at its coolest edge. We then compared the structure and composition of the herbivorous insect community that colonized the transplants (i) to that of the host plant species within its natural range and (ii) to a congeneric plant species that grew naturally at the transplant latitude. This experiment, therefore, tested whether characteristics of herbivorous communities on a host species in situ under a warmer climate may be predicted by their present day structure and composition or alternatively, by those on related plants in warmer environments.

We also investigated whether the herbivore community and rates of herbivory were affected by the latitudinal origin of the transplants. Ecotypic variation in traits such as foliage chemistry and phenology might be expected in a species with such a broad range (in this case encompassing $4.3^{\circ} \mathrm{C}$ mean annual temperature) (Hodgkinson \& Quinn, 1978; Roberds et al., 1990; King et al., 1995; Klingaman \& Oliver, 1996), which in turn might be expected to affect the assemblage of herbivores and the damage that the plants may incur. Herbi- vore assemblages and herbivory rates were compared among transplants originating from seed collected from four latitudes encompassing the natural coastal range of the focal host plant species.

The questions we addressed were:

1. Are herbivore communities structured differently on a host plant species in a warmer climate compared with those in the host's natural range?

2. Do rates of herbivory differ between a host plant species in a warmer climate compared with those in the host's natural range?

3. Does host plant ecotype influence herbivore community structure and herbivory in a warmer climate?

\section{Methods}

\section{Host plant species}

We focused on the host plant Acacia falcata Willd., a phyllodinous species (Family Fabaceae, subgenus Phyllodinae, section Phyllodineae) with an extensive latitudinal distribution along the east coast of Australia. The coastal distribution (at altitudes of $<150 \mathrm{~m}$ ) of A. falcata ranges from south of Moruya, New South Wales (NSW) $\left(35^{\circ} 53^{\prime} \mathrm{S}\right)$ to Tairo, Queensland (Qld) $\left(25^{\circ} 45^{\prime} \mathrm{S}\right)$, a distance of $1150 \mathrm{~km}$ (Fig. 1). A. falcata also

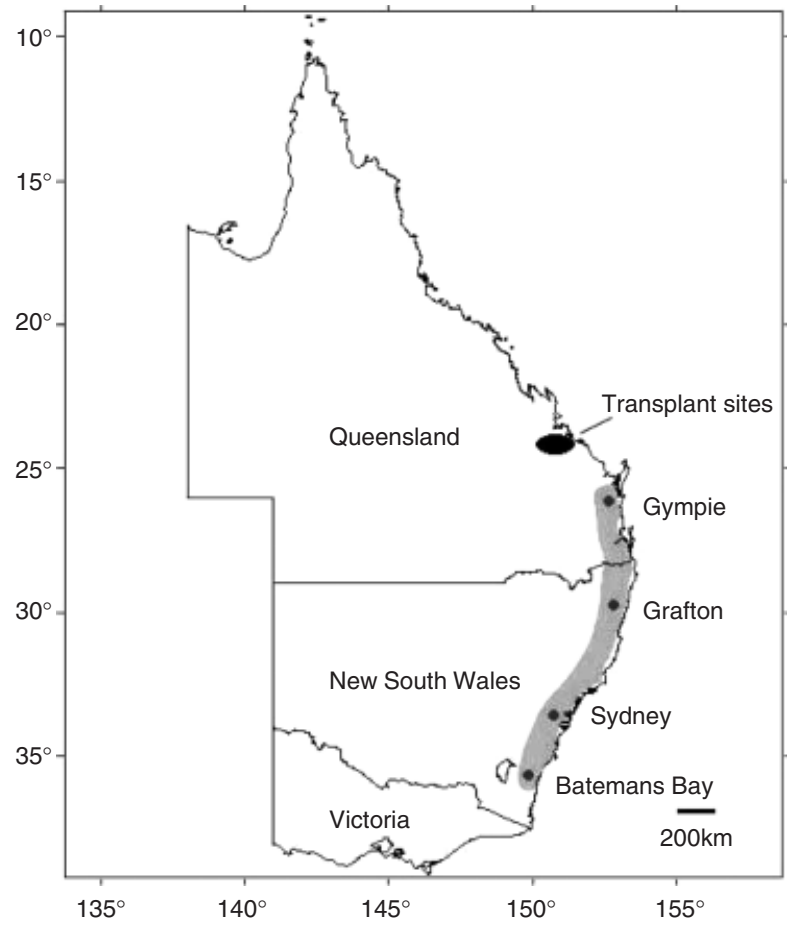

Fig. 1 Location of transplant sites in relation to the coastal distribution of Acacia falcata along the east coast of Australia and latitudes sampled within its range. 
occurs inland at higher altitudes from Bundara, NSW $\left(30^{\circ} 17^{\prime} \mathrm{S}\right)$ to Atherton, North Queensland $\left(17^{\circ} 22^{\prime} \mathrm{S}\right)$. We have previously characterized the arthropod communities on A. falcata throughout its coastal range in terms of the abundance and biomass of insect feeding guilds (Andrew \& Hughes, 2005a), species diversity of phytophagous Coleoptera (Andrew \& Hughes, 2004), and Hemiptera (Andrew \& Hughes, 2005b), and the rates of herbivory (Andrew \& Hughes, 2005c).

Seeds of A. falcata were collected in November 1999 from three sites at each of four latitudes encompassing the natural coastal range of the species (Fig. 1). The southern-most latitude used for seed collection was Batemans Bay, NSW $\left(35^{\circ} 40^{\prime} \mathrm{S}, 150^{\circ} 20^{\prime} \mathrm{E}\right)$, followed by Sydney, NSW (33 $\left.36^{\prime} \mathrm{S}, 150^{\circ} 52^{\prime} \mathrm{E}\right)$, Grafton, NSW $\left(29^{\circ} 44^{\prime} \mathrm{S}, 152^{\circ} 58^{\prime} \mathrm{E}\right)$ and the northern-most latitude, Gympie, Qld $\left(26^{\circ} 7^{\prime} \mathrm{S}, 153^{\circ} 11^{\prime} \mathrm{E}\right)$. This range spans $4.3^{\circ} \mathrm{C}$ mean annual temperature.

Seeds collected at different sites within latitudes were pooled and then treated with boiling water to promote germination. Once germinated, seeds were planted in sterilized potting mix in $5 \mathrm{~cm}$ diameter tubes and moved into a glasshouse at Macquarie University. Plants were transferred to $20 \mathrm{~cm}$ diameter pots once their roots were well developed and then grown for 1 year. A slow-release fertilizer (Osmocote ${ }^{\mathbb{B}}$ for Australian native plants, Baulkham Hills, NSW, Australia) was added to the potting mix three times according to the manufacturers' instructions: at the initial potting into $5 \mathrm{~cm}$ pots, during repotting into $20 \mathrm{~cm}$ pots, and 6 months later. Plants were watered twice daily for $5 \mathrm{~min}$ using an automated mist-spray sprinkler system and were subject to natural photoperiod.

In November 2000, the 1 year old plants were placed outside the glasshouse to acclimatize to natural weather conditions for 2 months. During this period, they were watered three times weekly. Most plants were over $2 \mathrm{~m}$ tall by this time and were subsequently cut back to $50 \mathrm{~cm}$ before transplantation.

\section{Study sites}

In February 2001, 160 plants were transplanted to two $20 \mathrm{~m}^{2}$ sites, $27 \mathrm{~km}$ apart: Dan Dan $\left(24^{\circ} 10^{\prime} 51^{\prime \prime} \mathrm{S}\right.$, $\left.151^{\circ} 05^{\prime} 16^{\prime \prime} \mathrm{E}\right)$ and Calliope $\left(23^{\circ} 57^{\prime} 04^{\prime \prime} \mathrm{S}, 151^{\circ} 10^{\prime} 55^{\prime \prime} \mathrm{E}\right)$ near Gladstone, central Queensland (Fig. 1). These sites, collectively known as the 'transplant latitude' hereafter, are approximately $280 \mathrm{~km}$ north of the northernmost coastal boundary of $A$. falcata (Gympie). Both transplant sites were open eucalypt woodland with 10-30\% canopy cover, with easterly aspect on clay soils. Mean annual temperature at the transplant sites was $21.4^{\circ} \mathrm{C}$, compared with that for Gympie $\left(20.2^{\circ} \mathrm{C}\right)$, Grafton $\left(18.3^{\circ} \mathrm{C}\right)$, western Sydney $\left(16.9^{\circ} \mathrm{C}\right)$ and Batemans Bay $\left(15.9^{\circ} \mathrm{C}\right)$
(BIOCLIM 5.0, Busby, 1991). Based on BIOLCLIM 5.0, the mean annual precipitation at the transplant sites was $919 \mathrm{~mm}$, which is lower than Gympie (1104 mm), Grafton $(1118 \mathrm{~mm})$ and Batemans Bay $(1145 \mathrm{~mm})$, but higher than western Sydney $(838 \mathrm{~mm})$.

Both transplant sites were fenced to exclude vertebrate herbivores. Eighty plants (20 plants from each of the four latitudes of origin) were randomly planted at each site at $1.5 \mathrm{~m}$ intervals in a $16 \mathrm{~m} \times 16 \mathrm{~m}$ grid, with a $2 \mathrm{~m}$ buffer from the fence. Plants were watered for 3 days after transplantation. Ten of the 160 trees (from various latitudes) died during the 12-month monitoring period after transplantation.

Five soil samples $(8 \mathrm{~cm}$ diameter $\times 13 \mathrm{~cm}$ depth, $653 \mathrm{~cm}^{3}$ ) were taken per transplant site, bulked, dried and sieved through $1 \mathrm{~mm}$ mesh. Total soil nitrogen for each site was assessed using a LECO CHN-2000 analyser (Leco Corporation, St Joseph, MI, USA) and total phosphorus using ICPOES Method \# 113 (Anonymous, 2000). Total $N$ and $P$ for the transplant sites (Dan Dan total N: $0.11 \% \mathrm{w} / \mathrm{w}$, total P: $220 \mathrm{mg} \mathrm{kg}^{-1}$; Calliope: total $\mathrm{N}: 0.07 \% \mathrm{w} / \mathrm{w}$, total P: $240 \mathrm{mg} \mathrm{kg}^{-1}$ ) was similar to the range found at sites within $A$. falcata's natural distribution (range total $\mathrm{N}: 0.07-0.20 \% \mathrm{w} / \mathrm{w}$, total P: $74-$ $237 \mathrm{mg} \mathrm{kg}^{-1}$ ) (Andrew \& Hughes, 2005c).

\section{Herbivore community structure}

Arthropods on the transplants were sampled in May 2001, November 2001 and February 2002. At each site, at each sampling time, five $A$. falcata plants from each collection latitude were haphazardly selected and sprayed with $0.6 \%$ pyrethrum/water solution in the morning on low-wind days, a total of 120 samples. All arthropods that fell onto two collecting trays $(50 \mathrm{~cm} \times 30 \mathrm{~cm})$ placed beneath the plants were transferred into vials containing $70 \%$ ethanol for storage. Collections were also made using the same methods on an equivalent number of $A$. leptostachya Benth. (subgenus Phyllodinae, section Juliflorae), at both transplant sites at each sampling period. After the February 2002 sample, all transplanted shrubs were destroyed, preflowering, to comply with scientific licensing conditions.

All Coleoptera and Hemiptera were identified to family and morphospecies. Adult morphospecies were formally identified as separate species by expert taxonomists. Only species classified as phytophagous were used in this study. Larvae and nymphs were excluded from the analysis because it is extremely difficult to associate juveniles with adults of the same species in preserved collections.

The Coleoptera and Hemiptera were classified into functional guilds according to their different feeding 
habits, evolutionary lineages and morphological characteristics (Lawrence \& Britton, 1991; Elliott et al., 1998; Peeters et al., 2001). Coleoptera were divided into leafchewers (species within the families Cerambycidae and Chrysomelidae: superfamily Chrysomeloidea) and weevils (species within the families Attelabidae, Belidae, Brentidae and Curculionidae: superfamily Curculionoidea). Hemiptera were divided into five guilds: phloem hoppers, phloem bugs, mesophyll hoppers, mesophyll bugs and xylem hoppers. Classification into each guild was based on the feeding habit and taxonomic relationship of each species as reported in CSIRO (1991), Peeters et al. (2001), Andrew \& Hughes (2004, 2005b) and from expert taxonomist advice (G. Cassis, M. Fletcher and G. Taylor). Phloem hoppers feed on phloem sap and were identified from the suborder Auchenorrhyncha including leafhoppers (most Cicadellidae subfamilies) and planthoppers (Fulgoroidea). Phloem bugs also feed on phloem sap and comprized species from the suborder Sternorrhyncha including psyllids (Psylloidea), aphids (Aphididae) and white flies (Aleyrodidae). Mesophyll hoppers feed on mesophyll fluid and were identified as leafhoppers from the suborder Auchenorrhyncha, family Cicadellidae, subfamily Typhlocybinae. Mesophyll bugs also feed on mesophyll fluid and included species from the Heteroptera (true bugs). Xylem hoppers feed on xylem fluid and comprised species from the suborder Auchenorrhyncha including froghoppers (Cercopidae) and leafhoppers from the family Cicadellidae, subfamily Cicadellinae.

Owing to the low number of herbivore species per shrub sampled, individual shrubs were pooled within latitudes of origin and for both transplant sites and three sampling times. G-tests were used to compare the proportion of species within guilds on the transplanted A. falcata to (i) a previously collected data set of arthropods from $A$. falcata throughout its natural range, sampled seasonally for 2 years (930 plants) (Andrew \& Hughes, 2004, 2005b) (hereafter referred to as the full data set, (ii) A. falcata plants from a subset of the current range, standardized to equivalent sample seasons and total number of individual plants as the transplanted plants (hereafter referred to the standardized data set) and (iii) the congeneric host species native to the transplant sites, A. leptostachya.

For the standardized data set, we used collections from 30 randomly chosen shrubs from each of the four latitudes (Batemans Bay, Sydney, Grafton and Gympie) from three of the eight seasonal samples made between November 1999 and February 2001 (November 2000, February 2001 and May 2001), a total of 120 samples.

We used a G-test to compare total species richness, and richness within the two herbivore taxa (Coleoptera and Hemiptera) among transplants originating from seeds collected at different latitudes (data collected from the two transplant sites were combined).

Owing to the different number of samples made between those along the latitudinal gradient and the transplant latitudes, species richness comparisons were also plotted as a function of the number of individuals collected (Gotelli \& Colwell, 2001; Andrew \& Hughes, 2005b). Accumulation (rarefaction) curves were generated to compare the species richness between $A$. falcata transplant shrubs and $A$. falcata plants within the natural range using ESTIMATE S 5.0 (Colwell, 1997). Species accumulation curves were standardized by comparing the number of species per 119 individuals (the lowest number collected from $A$. falcata at any of the latitudes or transplants). A. falcata samples used for this comparison were taken only from the standardized data set.

\section{Herbivory assessment}

An assessment of rates of herbivory was made on the transplanted shrubs following the protocols outlined in Andrew \& Hughes (2005c). Briefly, herbivore damage was assessed over a 12-month period, from February 2001 to February 2002. Five expanding phyllodes on one branch from each of five plants from each of the four latitudes were sequentially numbered using a waterbased permanent pen. Images of each phyllode were taken in situ using a digital camera. Three different types of herbivore damage (chewing, sap-sucking and mining) were identified and the area missing, relative to total phyllode area was assessed using IMAGE J software (Rasband, 2003).

To assess differences in herbivory among the four latitudes of origin, chewing, sap-sucking and mining herbivory per phyllode was measured over 12 months, from February 2001 to February 2002. Herbivory was compared both among latitudes of origin and transplant sites by a two-way multivariate analysis of variance (MANOVA), with plants originating from each of the four latitudes used as replicates (rates for individual phyllodes were averaged within plants) using DATADESK $^{\circledR}$ 6.1, (Data Description Inc., Ithaca, NY, USA) (Velleman, 1997). Pillai's trace was the test statistic used (Tabachnick \& Fidell, 2001; Quinn \& Keough, 2002).

To compare rates of herbivory at the transplant latitudes to those in the natural distribution, an average percentage herbivory for each damage type (chewing, sap-sucking and mining) at each transplant site was compared with a subset of a previously collected data set (Andrew \& Hughes, 2005c) over a comparable 12month period (February 2001 to February 2002). Average percentage herbivory per site, within each of the four natural distribution latitudes and the transplant 
latitude, were used as replicates (rates for individual phyllodes and plants were averaged). Percentage herbivory among the latitudes and transplants was compared using a one-way MANOVA using DATADESK ${ }^{\circledR} 6.1$. Pillai's trace was the test statistic used. By pooling samples across leaves and sites within latitudes we have taken into account much of the variation that occurs within latitudes. This does reduce the statistical power of these analyses but we believe that this method is appropriate for the questions addressed.

A priori power calculations were carried out for each of the hypotheses being tested. Analyses were calculated using GPOWER (Erdfelder et al., 1996) with Cohen's (1988) 'medium' effect size conventions used.

\section{Results}

\section{Herbivore community structure}

Eleven species of adult Coleoptera were collected from the transplanted shrubs: five from the Curculionidae, four from the Chrysomelidae and two from the Brentidae. Nineteen species of adult Hemiptera were collected: seven species from the Cicadellidae, three each from the Alyrodidae and Psyllidae, and a single species each from the Aphididae, Issidae, Lygaedae, Meenoplidae, Membracidae and Miridae.

Of the 30 species collected on the transplants, only five species were collected from previous samples of A. falcata within its natural range: four Hemiptera and one Coleoptera species (Table 1 - species in bold). Of these, Aphid sp. 4 and Calomela ioptera were common at both transplant sites. The three other species were sampled only once: Acizzia sp. 1 and Zygina ipoloa were sampled only at Calliope, while Acizzia sp. 2 was sampled only from Dan Dan.

Eight herbivore species, six Hemiptera and two Coleoptera, were collected from $A$. leptostachya (compared with 30 for the transplanted $A$. falcata). All eight species were also found on the transplants (Table 1).

Six feeding guilds were found on the transplants, compared with seven for the full data set sampled from the natural range of $A$. falcata: eight species of phloem hopper, seven species each of phloem bugs and weevils, four species of leaf beetle, two species of mesophyll bug and two species of mesophyll hopper. The seventh guild, xylem hoppers, was not found on the transplanted shrubs (but it should be noted that this guild was very sparse on $A$. falcata within its natural range as well). The proportion of species within each guild on the transplants was not significantly different from that of either the full data set collected $\left(G_{6}=7.50, P=0.28\right.$, power $=0.90)$, or the standardized data set $\left(G_{6}=9.3\right.$, $P=0.16$. power $=0.69)($ Fig. 2$)$. However, there were significant differences between guild structure on the transplanted $A$. falcata and the co-occurring A. leptostachya $\left(G_{6}=20.22, P<0.01\right.$, power $\left.=0.23\right)$ : compared with the transplanted A. falcata, A. leptostachya had a higher proportion of phloem bugs and mesophyll hoppers but a lower proportion of phloem hoppers and no mesophyll bugs. It should be noted, however, that the fauna of A. leptostachya was rather depauperate, so this comparison should be treated with some caution.

We compared species accumulation curves between the transplants and plants from the four latitudes within the natural distribution of A. falcata (Fig. 3). The transplants had a lower species accumulation at an equivalent number of individuals $(n=119)$ compared with collections from Sydney, Gympie and Batemans Bay but a higher number of species compared with Grafton.

Thirteen species were common to more than one transplant site (Table 1 - Group A). Eight species were found at both sites, while two species were found only at Dan Dan, and three were found only at Calliope. Two species dominated the herbivore community (Fig. 1), Alcidodes bulbo and Aphid-4. Together, these comprised $58 \%$ of the abundance of individual herbivores sampled. Seventeen species were rare, being collected from one plant at only one collection time (Table 1 Group B).

\section{Herbivory}

There were no significant differences in the overall rates of herbivory on $A$. falcata between the transplant location and the natural distribution latitudes (Table 2a, Fig. 4) and for two of the three component herbivory types, chewing and sap-sucking herbivory (Table 2b). Mining herbivory was significantly lower at the transplant sites $(0.55 \pm 0.29 \%)$ compared with Gympie $(5.86 \pm 2.34 \%)$ (Table 3b).

\section{Comparison between host plant latitudes of origin}

There were no significant differences in either the total number of species (Hemiptera and Coleoptera combined) $\left(G_{3}=2.1, P=0.55\right.$, power $\left.=0.24\right)$, or for either order compared separately (Coleoptera: $G_{3}=0.78$, $P=0.85$; Hemiptera: $G_{3}=1.90, P=0.59$, power $=0.15$ ) on the transplants originating from the four different collection latitudes.

There were no significant differences in the overall rate of herbivory among $A$. falcata plants from different latitudes of origin, nor among the component types of herbivory (Table 3). Similarly there was no significant difference in the overall rate of herbivory among transplant sites, however, there was a significantly higher 
Table 1 Abundance of phytophagous Coleoptera and Hemiptera collected from Acacia falcata transplants (latitudes of origin pooled) and Acacia leptostachya plants (native to sites) at two sites (Calliope and Dan Dan) near Gladstone, central Queensland

\begin{tabular}{|c|c|c|c|c|c|c|}
\hline \multirow[b]{2}{*}{ Feeding guild } & \multirow[b]{2}{*}{ Family } & \multirow[b]{2}{*}{ Herbivore species } & \multicolumn{2}{|c|}{ Acacia falcata } & \multicolumn{2}{|c|}{ Acacia leptostachya } \\
\hline & & & Dan Dan & Caliope & Dan Dan & Calliope \\
\hline \multicolumn{7}{|l|}{ Group A } \\
\hline Phloem bug & Aphididae & Aphid-4 & 17 & 27 & & 2 \\
\hline Phloem hopper & Cicadellidae & Cicad-T2 & 10 & 1 & & \\
\hline Leaf beetle & Chrysomelidae & Calomela ioptera (Baly) & 8 & 8 & & \\
\hline Phloem bug & Alyrodidae & Alyrod-T1 & 8 & 5 & 2 & \\
\hline Weevil & Brentidae & Apion-T1 & 3 & 6 & 1 & \\
\hline Phloem hopper & Cicadellidae & Cicad-T1 & 2 & 1 & 1 & \\
\hline Phloem hopper & Membracidae & Membr-T1 & 1 & 1 & & \\
\hline Mesophyll bug & Lygaedae & Saldid-3 & 1 & 1 & & \\
\hline Phloem hopper & Cicadellidae & Cicad-T1 & 3 & & & \\
\hline Mesophyll hopper & Cicadellidae & Cicad-T3 & 2 & & & \\
\hline Weevil & Brentidae & Alcidodes bubo (Fabricius) & & 76 & & 1 \\
\hline Weevil & Curculionidae & Curc-T2 & & 6 & & \\
\hline Phloem bug & Psyllidae & Acizzia sp. 1 & & 2 & 1 & 13 \\
\hline \multicolumn{7}{|l|}{ Group B } \\
\hline Phloem hopper & Cicadellidae & Mapochiella rotundata & 1 & & & \\
\hline Leaf beetle & Chrysomelidae & Chry-T1 & 1 & & & \\
\hline Weevil & Curculionidae & Curc-T4 & 1 & & & \\
\hline Phloem bug & Psyllidae & Acizz-T1 & 1 & & & \\
\hline Mesophyll hopper & Cicadellidae & Zygina ipoloa (Kirkaldy) & 1 & & 1 & \\
\hline Phloem hopper & Meenoplidae & Meeno-T1 & 1 & & & \\
\hline Phloem bug & Psyllidae & Acizzia sp. 2 & 1 & & & \\
\hline Phloem bug & Alyrodidae & Alyrod-4 & 1 & & & \\
\hline Mesophyll bug & Miridae & Mirid-T1 & 1 & & & \\
\hline Weevil & Curculionidae & Neolaemosaccus-T5 & & 1 & & \\
\hline Phloem hopper & Cicadellidae & Cicad-T2 & & 1 & & \\
\hline Leaf beetle & Chrysomelidae & Rhyparida sp. 2 & & 1 & 1 & 1 \\
\hline Leaf beetle & Chrysomelidae & Chry-T5 & & 1 & & \\
\hline Phloem bug & Alyrodidae & Alyrod-T3 & & 1 & & \\
\hline Weevil & Curculionidae & Nanophyes-T3 & & 1 & & \\
\hline Phloem hopper & Issidae & Issid-T1 & & 1 & & \\
\hline Weevil & Curculionidae & Curc-T6 & & 1 & & \\
\hline Number of species & & & 19 & 19 & 6 & 4 \\
\hline
\end{tabular}

Component feeding guilds and family associations are also included. Species in bold were also found on $A$. falcata within its current coastal distribution (see 'Results' for details). Group A species were common to more than one plant at more than one collection time. Group B species were rare, being collected from one plant at only one collection time.

amount of sap-sucking herbivory at Calliope $(1.44 \pm$ $1.69 \%)$ compared with Dan Dan $(0.47 \pm 0.79 \%)$. There were no significant interactions between latitude of origin and transplant site. It should be noted that across both sites, the rates of herbivory ranged from $1.9 \%$ to $88.7 \%$ per plant for phyllode chewing, $0 \%$ to $7.05 \%$ per plant for sap-sucking, and $0 \%$ to $6.7 \%$ per plant for phyllode-mining.

\section{Discussion}

Climate change will have profound impacts on most species and communities over the next century and beyond. Predicting both the magnitude and direction of these impacts for even single, well-studied species is difficult, and for whole suites of interacting species even more so (Voigt et al., 2003). Most predictions made to date have come from either small-scale experiments in which factors such as temperature and $\mathrm{CO}_{2}$ have been manipulated (e.g. Diaz et al., 1998; Dury et al., 1998; Buse et al., 1999; Johns \& Hughes, 2002), bioclimatic modelling (e.g. Woodward \& Rochefort, 1991; Brereton et al., 1995; Hughes et al., 1996; Kadman \& Heller, 1998; Hoegh-Guldberg, 1999; Beaumont \& Hughes, 2002), field studies along environmental gradients (e.g. Hill \& Hodkinson, 1992; Harrison, 1993; Whittaker \& Tribe, 
(a) Acacia falcata:
transplants

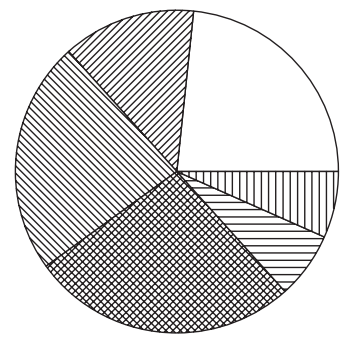

(c) Acacia falcata: standardised current distribution

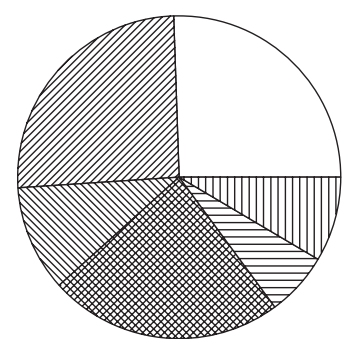

(b) Acacia falcata: current distribution

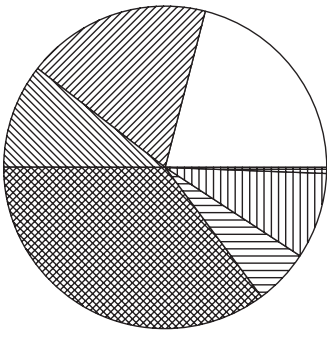

(d) Acacia leptostachya: transplant sites

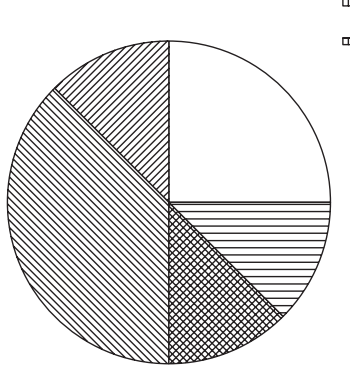

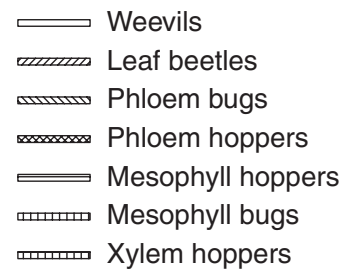

Xylem hoppers

Fig. 2 Herbivore guild composition on (a) transplanted Acacia falcata (b) A. falcata from its current range based on all samples collected (Andrew \& Hughes, 2004, 2005b), (c) A. falcata in current range based on an equivalent number of plants sampled as the transplants and (d) Acacia leptostachya, the native host plant at the transplant sites.

1996; Fielding et al., 1999; Hodkinson et al., 1999; Fleishman et al., 2000; Andrew \& Hughes, 2004, 2005b), and long-term studies at a few sites (e.g. Woiwod, 1997; Voigt et al., 2003). Transplant experiments offer a useful complement to these approaches and can be used to address broad questions about how communities might be structured and composed in the future.

In this study, we found that the herbivore assemblage collected from transplanted shrubs had a similar guild structure to that of the host within its current geographic range and was significantly different from the assemblage on a congeneric species at the transplant site. This suggests that community structure, based on the relative number of species in the guilds we identified, may be influenced more by the particular characteristics of the host plant species (be they chemical or physical) than by climate. The somewhat depauperate herbivore fauna on $A$. leptostachya compared with A. falcata, however, means that differences in guild structure between hosts at the transplant sites need to be interpreted with some caution.

The insect assemblages we collected included adult representatives from the major feeding guilds also found within the natural range of $A$. falcata, except for xylem feeders. Adult xylem feeders were also rare in the main range of $A$. falcata (sampled only at Batemans Bay - the most temperate latitude), and their

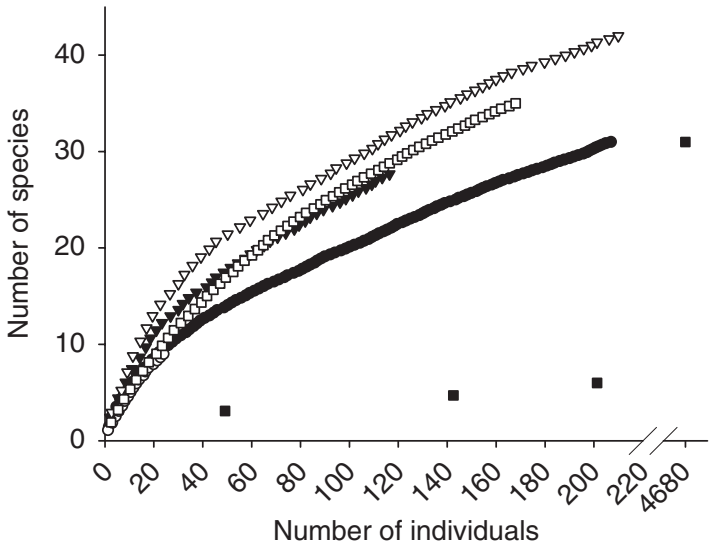

- A. falcata transplants

- A. leptostachya

- A. falcata Gympie

- A. falcata Grafton

$\checkmark$ A. falcata Sydney

- A. falcata Batemans Bay

Fig. 3 Rarefaction curve (Coleman curve) of species collected from Acacia falcata at the transplant sites and Acacia leptostachya, native to the transplant sites and A. falcata at each of four latitudes in its current distribution, per number of individuals collected, from the standardized data set. See 'Methods' for sampling details.

absence from the data set may be due to them being collected only as nymphs (which were not assessed in this study). 
Table 2 Summary table of MANOVA statistics (a) rate of herbivory among the transplant latitudes and latitudes in the natural distribution of $A$. falcata and (b) ANOVA statistics for component herbivory types

\begin{tabular}{|c|c|c|c|c|c|c|c|c|c|}
\hline Variable & \multicolumn{3}{|c|}{$\mathrm{df}$} & \multicolumn{2}{|l|}{ Pillai trace } & Approx $F$ & \multicolumn{2}{|c|}{$P$} & Power \\
\hline \multicolumn{10}{|l|}{ (a) } \\
\hline \multirow[t]{2}{*}{ Latitude } & \multicolumn{2}{|r|}{12,24} & & \multirow[t]{2}{*}{1.34} & & \multirow[t]{2}{*}{1.61} & \multicolumn{2}{|c|}{0.15} & 0.25 \\
\hline & \multirow[b]{2}{*}{$\mathrm{df}$} & & Chewing & & Sucking & & \multicolumn{2}{|c|}{ Mining } & \multirow[b]{2}{*}{ Power } \\
\hline Variable & & & $F$ & $P$ & $F$ & $P$ & $F$ & $P$ & \\
\hline \multicolumn{10}{|l|}{ (b) } \\
\hline Latitude & 4,8 & & 0.47 & 0.76 & 1.84 & 0.22 & 3.84 & 0.05 & 0.25 \\
\hline
\end{tabular}

Significant values in bold. A priori power calculations included.

Of the 30 species of herbivorous Coleoptera and Hemiptera collected on the transplanted A. falcata, only five were found on A. falcata within its current range. The four hemipterans, Acizzia sp. 1, Acizzia sp. 2, Aphid sp. 4 and Zygina ipoloa were cosmopolitan in distribution in the natural range (i.e. found at more than one latitude and on other, co-occurring acacias) (Andrew \& Hughes, 2005b). Calomela ioptera (Coleoptera), was identified as a specialist species in the natural range being only found on one plant at Gympie at one sampling time (i.e. rare) (Andrew \& Hughes, 2004), but was relatively common on transplants: this species is also known to feed on a range of Acacia species along the east coast of Australia (Reid, 1989).

The transplantation of $A$. falcata into a warmer climate, therefore, demonstrated that a suite of new insect herbivore species may colonize $A$. falcata within its current range over the coming century, assuming the plant's most tropical boundary does not move poleward at the same pace as the insects. Changes in composition within transplanted plant communities have previously been found (e.g. Bruelheide, 2003) but to our knowledge there have been no other published studies in which insect communities on transplanted plants have been assessed.

The number of species that colonized the transplanted $A$. falcata over 12 months was lower than that found at three of the four latitudes within the natural range. Grafton had a low species accumulation when plotted against abundance to other latitudes and the transplant sites, due to samples being dominated $(96 \%$ of total abundance) by a single herbivore species: Acizzia sp. 2 (Andrew \& Hughes, 2005b). The transplanted shrubs used in this study were younger and smaller than those sampled within the natural range of A. falcata in our previous studies (N. R. Andrew \& L. Hughes, unpublished data). It might have been anticipated, therefore, that the transplanted $A$. falcata

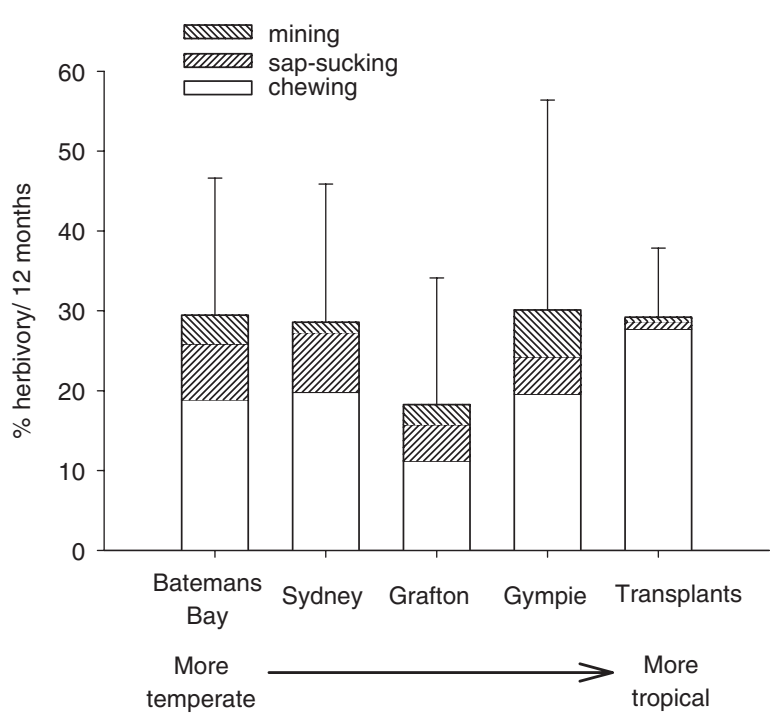

Fig. 4 Average rate of phyllode herbivory $( \pm S D)$ including chewing, sap-sucking and mining on Acacia falcata at four latitudes in its natural coastal distribution and the transplant latitude.

would have a more depauperate herbivore community compared with that of the more architecturally complex A. falcata shrubs within the natural range (Leather, 1986). Our finding that the guild structure of the transplants did not differ significantly between the transplants and either the full data set of arthropods sampled within the natural range, or the data set subsampled to equivalent sample size, indicated that the differences in size between the plants had little effect on the community collected. Furthermore, we found that the community collected on A. leptostachya, which is a small tree (up to $4 \mathrm{~m}$ in height) was actually lower in species richness than the transplanted $A$. falcata shrubs.

We found no differences in the diversity of herbivore species among $A$. falcata transplants grown from seeds 
Table 3 Summary of MANOVA statistics (a) Rate of herbivory on A. falcata among different latitudes of origin and (b) ANOVA statistics for component herbivory types. A priori power calculations included

\begin{tabular}{|c|c|c|c|c|c|c|c|c|c|}
\hline Variable & \multicolumn{3}{|c|}{$\mathrm{df}$} & \multicolumn{2}{|l|}{ Pillai trace } & Approx $F$ & \multicolumn{2}{|c|}{$P$} & Power \\
\hline \multicolumn{10}{|l|}{ (a) } \\
\hline Latitude & \multicolumn{3}{|c|}{9,84} & \multicolumn{2}{|l|}{0.30} & 1.04 & \multicolumn{2}{|c|}{0.42} & 0.82 \\
\hline Site & \multicolumn{3}{|c|}{3,26} & \multicolumn{2}{|l|}{0.22} & 2.46 & \multicolumn{2}{|c|}{0.09} & 0.93 \\
\hline \multirow[t]{2}{*}{ Latitude * site } & \multicolumn{2}{|r|}{9,84} & & 0.35 & & 1.37 & \multicolumn{2}{|c|}{0.21} & 0.82 \\
\hline & \multirow{2}{*}{\multicolumn{2}{|c|}{$\mathrm{df}$}} & \multicolumn{2}{|c|}{ Chewing } & \multicolumn{2}{|c|}{ Sucking } & \multicolumn{2}{|c|}{ Mining } & \multirow[b]{2}{*}{ Power } \\
\hline Variable & & & $F$ & $P$ & $F$ & $P$ & $F$ & $P$ & \\
\hline \multicolumn{10}{|l|}{$(b)$} \\
\hline Latitude & 3,28 & & 0.46 & 0.71 & 2.32 & 0.10 & 0.74 & 0.54 & 0.46 \\
\hline Site & 1,28 & & 2.47 & 0.13 & 5.63 & 0.02 & 1.01 & 0.32 & 0.66 \\
\hline Latitude * site & 3,28 & & 1.57 & 0.22 & 0.62 & 0.61 & 2.25 & 0.10 & 0.46 \\
\hline
\end{tabular}

collected at different latitudes. While many of the herbivores collected from the transplants were unique to plants originating from one latitude, all were singleton occurrences. Their presence on plants from one particular latitude was therefore, likely to be due to the lack of sampling rather than a preference for transplants from a particular latitude.

There were no significant differences in the rate of herbivory on $A$. falcata among latitudes of origin. There was also no significant difference in the rate of herbivory within the natural range and between the transplanted A. falcata. This is in contrast to studies that have concluded that herbivory increases towards the tropics for a range of plant species and habitats (Dyer \& Coley, 2002). The most specialized type of herbivory, mining, was significantly lower on the transplanted shrubs compared with only the most northerly latitude (Gympie). We expected a lower rate of mining herbivory at the transplant latitude due to the short period of time miners had to adapt to a new host plant species, compared with rates of mining herbivory in the natural distribution. Rates of herbivory of a more general nature (chewing and sap-sucking) did not change significantly between the transplants and the natural distribution of $A$. falcata. This is possibly explained by generalist herbivores taking less time to adapt to a novel host plant compared with specialist herbivore feeders. Interestingly Bruelheide (2003), found herbivory by a generalist slug increased on plots of montane meadow translocated from high altitude to low altitude. A more detailed analysis of which specific taxa were causing the most chewing damage (in our case Coleoptera or Orthoptera) would be interesting, but was outside the scope of this study.
In summary, we found that guild structure of herbivorous Hemiptera and Coleoptera was similar between host plants transplanted to a warmer climate and the same host species within its current range. The overlap in actual insect species identity between the transplants and the current range, however, was quite low. Similarly, rates of herbivory were similar on A. falcata in a warmer climate compared with populations within its natural range. If these results can be generalized to other plant hosts, we might predict that as climate zones shift poleward and mobile organisms like flying insects respond by migrating to stay within their current climatic envelope, plants will be colonized by new herbivore species within similar guilds to those currently supported. Changes in the composition, but not necessarily the structure, of these new communities may, therefore, result. Damage to the plants (as measured by rates of herbivory) by these new suites of herbivores might also be similar in a warmer climate. Similar types of experiments in other regions and for other host species will be needed to test these predictions.

\section{Acknowledgements}

We wish to thank Julie Lee Yaw for helping setting up the transplant sites, the Ariens family who allowed us to set up one site on their leasehold property (Dan Dan site) and the Department of Natural Resources, Rockhampton, Qld for scientific licences and logistical support. Scott Ginn assisted in invertebrate sorting and morphospecies identification. Gerry Cassis, Murray Fletcher, Birgit Schürrer, Chris Reid, Rolf Oberprieler, Gary Taylor and Tom Weir provided taxonomic assistance. Rob Colwell, Saul Cunningham and Jonathan Majer kindly commented on earlier drafts of this manuscript. This 
project was undertaken while N. R. A. was the recipient of an Australian Postgraduate Award and was financially supported by a Macquarie University Research Grant. Contribution number 410 from the Key Centre for Biodiversity and Bioresources, Macquarie University.

\section{References}

Andrew NR, Hughes L (2004) Species diversity and structure of phytophagous beetle assemblages along a latitudinal gradient: predicting the potential impacts of climate change. Ecological Entomology, 29, 527-542.

Andrew NR, Hughes L (2005a) Arthropod community structure along a latitudinal gradient: implications for future impacts of climate change. Austral Ecology, 30, 281-297.

Andrew NR, Hughes L (2005b) Diversity and assemblage structure of phytophagous Hemiptera along a latitudinal gradient: predicting the potential impacts of climate change. Global Ecology and Biogeography, 14, 249-262.

Andrew NR, Hughes L (2005c) Herbivore damage along a latitudinal gradient: relative impacts of different feeding guilds. Oikos, 108, 176-182.

Anonymous (2000) Determination of calcium, magnesium, phosphorous, potassium and Sodium in soil and sediment by block digestion (ICPOES): method \#113. State Chemistry Laboratory, Melbourne.

Beaumont LJ, Hughes L (2002) Potential changes in the distributions of latitudinally restricted Australian butterfly species in response to climate change. Global Change Biology, 8, 954-971.

Brereton R, Bennett S, Mansergh I (1995) Enhanced greenhouse climate change and its potential effect on selected fauna of south-eastern Australia: a trend analysis. Biological Conservation, 72, 339-354.

Bruelheide H (2003) Translocation of a montane meadow to simulate the potential impacts of climate change. Applied Vegetation Science, 6, 23-34.

Busby JR (1991) BIOCLIM - a bioclimatic analysis and prediction system. Plant Protection Quarterly, 6, 8-9.

Buse A, Dury SJ, Woodburn RJW, Perrins CM, Good JEG (1999) Effects of elevated temperature on multi-species interactions: the case of pedunculate oak, winter moth and tits. Functional Ecology, 13, 74-82.

Cohen J (1988) Statistical Power Analysis for the Behavioral Sciences, 2nd edn. Erlbaum, Hillsdale.

Colwell RK (1997) EstimateS: statistical estimation of species richness and shared species from samples. Version 6.0. http://viceroy. eeb.uconn.edu/estimates

Crozier L (2002) Climate change and its effect on species range boundaries: a case study of the sachem skipper butterfly, Atalopedes campestris. In: Wildlife Responses to Climate Change: North American Case Studies (eds Schneider SH, Root TL), pp. 57-92. Island Press, Washington.

CSIRO (1991) The Insects of Australia, Vols. I and II. Melbourne University Press, Melbourne.

CSIRO (2001) Climate Change: Projections for Australia. Climate Impact Group, CSIRO Division of Atmospheric Research, Melbourne, http://www.dar.csiro.au/publications/projections2001.pdf
Diaz S, Fraser LH, Grime JP, Falczuk V (1998) The impact of elevated $\mathrm{CO}_{2}$ on plant-herbivore interactions: experimental evidence of moderating effects at the community level. Oecologia, 117, 177-186.

Dury SJ, Good JEG, Perrins CM, Buse A, Kaye T (1998) The effects of increasing $\mathrm{CO}_{2}$ and temperature on oak leaf palatability and the implications for herbivorous insects. Global Change Biology, 4, 55-61.

Dyer LA, Coley PD (2002) Tritrophic interactions in tropical versus temperate communities. In: Multitrophic Level Interactions (eds Tscharntke T, Hawkins BA), pp. 67-88. Cambridge University Press, Cambridge.

Elliott HJ, Ohmart CP, Wylie FR (1998) Insect Pests of Australian Forests: Ecology and Management. Inkata Press, Melbourne.

Erdfelder E, Faul F, Buchner A (1996) GPOWER: a general power analysis program. Behavior Research Methods, Instruments, and Computers, 28, 1-11.

Fielding CA, Whittaker JB, Butterfield JEL, Coulson JC (1999) Predicting responses to climate change: the effect of altitude and latitude on the phenology of the Spittlebug Neophilaenus lineatus. Functional Ecology, 13, 65-73.

Fleishman E, Fay JP, Murphy DD (2000) Upsides and downsides: contrasting topographic gradients in species richness and associated scenarios for climate change. Journal of Biogeography, 27, 1209-1219.

Gotelli NJ, Colwell RK (2001) Quantifying biodiversity: procedures and pitfalls in the measurement and comparison of species richness. Ecology Letters, 4, 379-391.

Harrington R, Fleming RA, Woiwod IP (2001) Climate change impacts on insect management and conservation in temperate regions: can they be predicted? Agricultural and Forest Entomology, 3, 233-240.

Harrison S (1993) Species diversity, spatial scale, and global change. In: Biotic Interactions and Global Change (eds Kareiva PM, Kingsolver JG, Huey RB), pp. 388-401. Sinauer Associates, Massachusetts.

Hill JK, Hodkinson ID (1992) Effects of temperature on phenological synchrony and altitudinal distribution of jumping plant lice (Hemiptera: Psylloidea) on dwarf willow (Salix lapponum) in Norway. Ecological Entomology, 20, 237-244.

Hobbie SE, Chapin FS (1998) An experimental test of limits to tree establishment in Arctic tundra. Journal of Ecology, 86, 449-461.

Hodgkinson KC, Quinn JA (1978) Environmental and genetic control of reproduction in Danthonia ceaspitosa populations. Australian Journal of Botany, 26, 351-364.

Hodkinson ID, Bird J, Miles JE, Bale JS, Lennon JJ (1999) Climatic signals in the life histories of insects: the distribution and abundance of heather psyllids (Strophingia spp.) in the UK. Functional Ecology, 13, 83-95.

Hoegh-Guldberg O (1999) Climate change, coral bleaching and the future of the world's coral reefs. Marine and Freshwater Research, 50, 839-866.

Hughes L (2000) Biological consequences of global warming: is the signal already apparent? Trends in Ecology and Evolution, 15, 56-61.

Hughes L, Cawsey E, Westoby M (1996) Climate range sizes of Eucalyptus species in relation to future climate change. Global Ecology and Biogeography Letters, 5, 128-142. 
Huntley B, Webb T (1989) Migration: species' response to climatic variations caused by changes in the Earth's orbit. Journal of Biogeography, 16, 5-19.

IPCC (2001) Climate change 2001: synthesis report - summary for policymakers. Intergovernmental Panel on Climate Change, http://www.ipcc.ch/pub/SYRspm.pdf

Johns CV, Hughes L (2002) Interactive effects of elevated $\mathrm{CO}_{2}$ and temperature on the leaf-miner Dialectica scalariella Zeller (Lepidoptera: Gracillariidae) in Paterson's Curse, Echium plantagineum (Boraginaceae). Global Change Biology, 8, 142-152.

Jones CG, Lawton JH (1991) Plant chemistry and insect species richness of British umbellifers. Journal of Animal Ecology, 60, 767-777.

Kadman R, Heller J (1998) Modelling faunal responses to climatic gradients with GIS: land snails as a case study. Journal of Biogeography, 25, 527-539.

King RW, Pate JS, Johnston J (1995) Ecotypic differences in the flowering of Pimelea ferruginea (Thymelaeaceae) in response to cool temperatures. Australian Journal of Botany, 44, 47-55.

Klingaman TE, Oliver LR (1996) Existence of ecotypes among populations of entireleaf morning glory (Ipomoea hederacea var integriuscula). Weed Science, 44, 540-544.

Kremen C, Colwell RK, Erwin TL, Murphy DD, Noss RF, Sanjayan MA (1993) Terrestrial arthropod assemblages - their use in conservation planning. Conservation Biology, 7, 796-808.

Lawrence JF, Britton EB (1991) Coleoptera. In: The Insects of Australia: A Textbook for Students and Research Workers (eds CSIRO), pp. 543-683. Melbourne University Press, Melbourne.

Leather SR (1986) Insect species richness of the British Rosaceae: the importance of host range, plant architecture, age of establishment, taxonomic isolation and species-area relationships. Journal of Animal Ecology, 55, 841-860.

Parmesan C, Ryrholm N, Stefanescu C et al. (1999) Poleward shifts in geographical ranges of butterfly species associated with regional warming. Nature, 399, 579-583.

Peeters PJ, Read J, Sanson GD (2001) Variation in the guild composition of herbivorous insect assemblages among cooccurring plant species. Austral Ecology, 26, 385-399.

Price PW (2002) Species interactions and the evolution of biodiversity. In: Plant-Animal Interactions: An Evolutionary Approach (eds Herrera CM, Pellmyr O), pp. 3-25. Blackwell Science, Oxford.
Quinn GP, Keough MJ (2002) Experimental Design and Data Analysis for Biologists. Cambridge University Press, Cambridge.

Rasband W (2003) Image J, 1.30. National Institutes of Health, http://rsb.info.nih.gov/ij/

Reid CAM (1989) A new species of Calomela Hope (Coleoptera: Chrysomelidae) from New South Wales, with habitat and distribution notes on other species in the genus. Australian Entomological Magazine, 16, 69-73.

Roberds JH, Hyun JO, Namkoong G, Rink G (1990) Height response functions for white ash provenances grown at different latitudes. Silvae Genetica, 39, 121-129.

Root TL, Price JT, Hall KR, Schneider SH, Rosenzweig C, Pounds JA (2003) Fingerprints of global warming on wild animals and plants. Nature, 421, 57-60.

Shaw MR, Harte J (2001) Control of litter decomposition in a subalpine meadow-sagebrush steppe ecotone under climate change. Ecological Applications, 11, 1206-1223.

Tabachnick BG, Fidell LS (2001) Using multivariate statistics, 4th edn. Allyn and Bacon, Boston.

Velleman PF (1997) DataDesk, 6.1. Data Description Inc. http:// www.datadesk.com/

Voigt W, Perner J, Davis AJ et al. (2003) Trophic levels are differentially sensitive to climate. Ecology, 84, 24442453.

Walther G-R, Post E, Convey P et al. (2002) Ecological responses to recent climate change. Nature, 416, 389-395.

Webb T (1992) Past changes in vegetation and climate: lessons for the future. In: Global Warming and Biological Diversity (eds Peters RL, Lovejoy TE), pp. 59-75. Yale University Press, New Haven.

Whittaker JB, Tribe NP (1996) An altitudinal transect as an indicator of responses of a spittlebug (Auchenorrhyncha: Cercopidae) to climate change. European Journal of Entomology, 93, 319-324.

Wieder RK, Yavitt JB (1994) Peatlands and global climate change: insights from comparative studies of sites situated along a latitudinal gradient. Wetlands, 14, 229-238.

Woiwod IP (1997) Detecting the effects of climate change on Lepidoptera. Journal of Insect Conservation, 1, 149-158.

Woodward FI, Rochefort L (1991) Sensitivity analysis of vegetation diversity to environmental change. Global Ecology and Biogeography Letters, 1, 7-23. 